\title{
Interaction and Binding Modes of bis-Ruthenium(II) Complex to Synthetic DNAs
}

\author{
Hasi Rani Barai ${ }^{1}$, Dong Jin Lee ${ }^{2}$, Sung Wook Han ${ }^{3}$ and Yoon Jung Jang ${ }^{4, *}$ \\ 1 Department of Chemistry, Yeungnam University, Dae-dong, Gyeongsan City, Gyeong-buk 712-749, Korea; \\ hrbarai@ynu.ac.kr \\ 2 Department of Chemical Engineering, Kyungil University, Gyeongsan City, Gyeong-buk 712-701, Korea; \\ djlee@kiu.ac.kr \\ 3 Department of Environmental Engineering, Kyungwoon University, Sangdong-myun, Gumi, \\ Gyeong-buk 136-701, Korea; swhan@ikw.ac.kr \\ 4 College of Basic Education, Yeungnam University, Dae-dong, Gyeongsan City, Gyeong-buk 712-749, Korea \\ * Correspondence: jyj5014@ynu.ac.kr; Tel.: +82-53-810-7833; Fax: +82-53-815-5412
}

Academic Editor: Grasso Giuseppe

Received: 19 April 2016; Accepted: 11 June 2016; Published: 16 June 2016

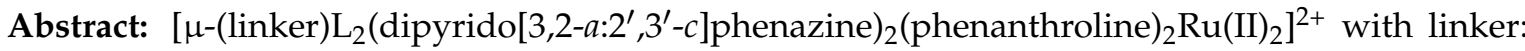
1,3-bis-(4-pyridyl)-propane, L: $\mathrm{PF}_{6}$ (bis-Ru-bpp) was synthesized and their binding properties to a various polynucleotides were investigated by spectroscopy, including normal absorption, circular dichroism(CD), linear dichroism(LD), and luminescence techniques in this study. On binding to polynucleotides, the bis-Ru-bpp complex with poly[d(A-T $\left.)_{2}\right]$, and poly[d(I-C $\left.)_{2}\right]$ exhibited a negative $\mathrm{LD}^{\mathrm{r}}$ signal whose intensity was as large as that in the DNA absorption region, followed by a complicated $\mathrm{LD}^{\mathrm{r}}$ signal in the metal-to-ligand charge transfer region. Also, the emission intensity and equilibrium constant of the bis-Ru-bpp complex with poly[d(A-T $\left.)_{2}\right]$, and poly[d(I-C $\left.)_{2}\right]$ were enhanced. It was reported that both of dppz ligand of the bis-Ru-bpp complex intercalated between DNA base-pairs when bound to native, mixed sequence DNA. Observed spectral properties resemble to those observed for poly $\left[\mathrm{d}(\mathrm{A}-\mathrm{T})_{2}\right]$ and poly $\left[\mathrm{d}(\mathrm{I}-\mathrm{C})_{2}\right]$, led us to be concluded that both dppz ligands intercalate between alternated AT and IC bases-pairs In contrast when bis-Ru-bpp complex was bound to poly $\left[\mathrm{d}(\mathrm{G}-\mathrm{C})_{2}\right]$, the magnitude of the $\mathrm{LD}^{\mathrm{r}}$ in the dppz absorption region, as well as the emission intensity, was half in comparison to that of bound to poly[d(A-T) $\left.)_{2}\right]$, and poly[d(I-C) $\left.)_{2}\right]$. Therefore the spectral properties of the bis-Ru-bpp-poly $\left[\mathrm{d}(\mathrm{G}-\mathrm{C})_{2}\right]$ complex suggested deviation from bis-intercalation model in the poly $\left[\mathrm{d}(\mathrm{G}-\mathrm{C})_{2}\right]$ case. These results can be explained by a model whereby one of the dppz ligands is intercalated while the other is exposed to solvent or may exist near to phosphate. Also it is indicative that the amine group of guanine in the minor groove provides the steric hindrance for incoming intercalation binder and it also takes an important role in a difference in binding of bis-Ru-bpp bound to poly[d(A-T $\left.)_{2}\right]$ and poly $\left[\mathrm{d}(\mathrm{I}-\mathrm{C})_{2}\right]$.
\end{abstract}

Keywords: bis-Ru(II) complex; intercalation; polynucleotides; light switch effect; luminescence; polarized spectroscopy

\section{Introduction}

The biopolymer DNA is the primary carrier of all genetic information. The central dogma of molecular biology underlines its central role in the storage and replication of genes. Through the RNA mediated processes of transcription and translation, DNA provides the "master genetic blueprint" for the construction of each protein required by individual cells. Consequently, synthetic molecules that interact with nucleic acids or modulate their function have been found as a variety of uses, such as biophysical and therapeutic agents [1]. In many ways, coordination complexes are ideal 
templates for the design of DNA-interactive systems, and the interaction of these structurally complex three-dimensional architectures with DNA has been continuously studied. In addition to a variety of binding modes, metal complexes also show distinctive chemical activities. They can coordinate directly to DNA Lewis base sites and undergo redox reactions with DNA or generate reactive oxygen containing species (an attribute particularly relevant to photodynamic therapy, PDT) [2-5]. The ability to bind and to cleave DNA and interfere with the essential interaction of various transition metal complexes with DNA have been the subject of intense study due to their unique physical properties and potential applications in biology [6-12].

Interaction of the various bis-Ru(II) complexes with DNA has also been reported [13-19].

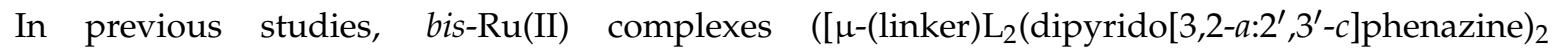
(phenanthro-line $\left.)_{2} \mathrm{Ru}(\mathrm{II})_{2}\right]^{2+} \quad$ with linkers: 4,4'-bipyridine; 1,2-bis-(4-pyridyl)-ethane; 1,3-bis-(4-pyridyl)-propane, $\mathrm{L}=\mathrm{Cl}$ or $\mathrm{PF}_{6}$ ), and its binding property with DNA was investigated by changing the length of bridge connecting ruthenium [20]. The length between the two Ru(II) complexes may be barely long enough to accommodate one DNA base between the two dppz ligands, but not for two DNA bases. When the linker was shorter (4,4'-bipyridine or 1,2-bis-(4-pyridyl)-ethane), the magnitude of the LD in the dppz absorption region, as well as the luminescence intensity of both bis-Ru(II) complexes was half that of the bis-Ru(II) complex bearing a long linker. Subsequent studies focused on biological and therapeutic applications such as inhibiting the transcription [21] or replication [22] of specific sequences, and preventing cellular proteins from binding to their designated target DNA [23] as well as on the design of artificial sequence specific nucleases [24].

In this study, interaction of bis-Ru-bpp complexes, chemical structures shown in Scheme 1, with polynucleotides are reported. As shown in the Scheme 1 , the $\left[\mu\right.$-(linker) $\mathrm{L}_{2}$ (dipyrido phenazine $)_{2}$ (phenanthroline $\left.)_{2} \mathrm{Ru}(\mathrm{II})_{2}\right]^{2+}$ with linker: 1,3-bis-(4-pyridyl)-propane, L: $\mathrm{PF}_{6}$. (here after referred to as bis-Ru-bpp) complex, possessing two intercalating dppz ligands, are connected by bridges, thereby allowing effective investigation of the binding mode of the bis-Ru-bpp complex bound to polynucleotides.

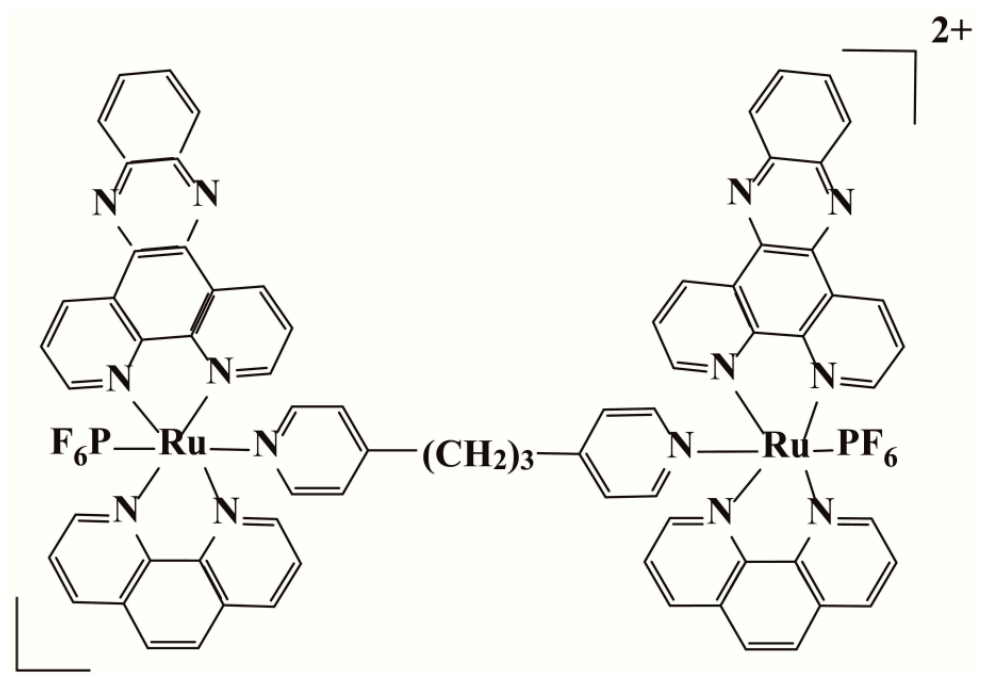

Scheme 1. Chemical structures of the $\left[\mu\right.$-(linker) $\mathrm{L}_{2}$ (dipyrido[3,2-a:2', $\left.3^{\prime}-c\right]$ phenazine) ${ }_{2}$ (phenanthro line $\left.)_{2}-\mathrm{Ru}(\mathrm{II})_{2}\right]^{2+}$ with linker: 1,3-bis-(4-pyridyl)-propane, $\mathrm{L}$ : $\mathrm{PF}_{6}$. In the text, this molecule is denoted as bis-Ru-bpp.

\section{Experimental Section}

Polynucleotides were purchased from Sigma Aldrich and purified by dissolution (exhaustive shaking at $4^{\circ} \mathrm{C}$ ) in a $5.0 \mathrm{mM}$ cacodylate buffer at $\mathrm{pH} 7.0$. The latter buffer was used throughout this work. Polyethyleneglycol(PEG) 8000 for inducing molecular crowding condition and other 
chemicals were purchased from Aldrich or Merck and used without purification. bis-Ru-bpp complex was prepared by the reported procedure [20]. Although $\mathrm{PF}_{6}{ }^{-}$is ligated in Scheme 1, it is very possible that this ligand is replaced by $\mathrm{H}_{2} \mathrm{O}$ or other stronger ligands in an aqueous environment. However, nature of this ligand may not affect the binding mode of the bis-Ru-bpp complex to DNA because the expanded dppz and phenanthroline ligand are the conceivable moiety that interact with DNA bases or phosphate groups (see Sections 3 and 4). The mixing ratio, $R$, was defined by the ratio of the concentration of the dppz of the complex per DNA base or phosphate concentration. Therefore, for instance, $R=0.1$ indicates five bis-Ru-bpp complex (or $10 \mathrm{dppz}$ moieties) per $100 \mathrm{DNA}$ bases or phosphate. The concentrations of bis-Ru-bpp complex and polynucleotides were determined spectrophotometrically using their proper molar extinction coefficients: $\varepsilon_{372 \mathrm{~nm}}=29,680 \mathrm{M}^{-1} \cdot \mathrm{cm}^{-1}$ for bis-Ru-bpp complex, $\varepsilon_{262 \mathrm{~nm}}=6600 \mathrm{M}^{-1} \cdot \mathrm{cm}^{-1}, \varepsilon_{254 \mathrm{~nm}}=8400 \mathrm{M}^{-1} \cdot \mathrm{cm}^{-1}$, and $\varepsilon_{251 \mathrm{~nm}}=6900 \mathrm{M}^{-1} \cdot \mathrm{cm}^{-1}$ for poly $\left[\mathrm{d}(\mathrm{A}-\mathrm{T})_{2}\right]$, poly $\left[\mathrm{d}(\mathrm{G}-\mathrm{C})_{2}\right]$, and poly $\left[\mathrm{d}(\mathrm{I}-\mathrm{C})_{2}\right]$ respectively.

Absorption spectra were recorded on a Cary 100 (Varian, Palo Alto, CA, USA). Circular and linear dichroism spectra (Referred to as CD and LD respectively) were measured on a J715 and J810 (Jasco, Tokyo, Japan) spectropolarimeter, respectively. The length of polynucleotides was too short, so LD could not be measured. LD has been used a powerful tool to explain DNA binding mode. Therefore, LD was measured by raising viscosity which was one of orientation factors that could influence LD value in order to obtain $L D$ value of polynucleotides. The molecular crowding condition was used as a method to raise viscosity. Physiological fluid media contains macromolecules collectively occupying between a lower limit of about $7 \%$ and an upper limit of about $40 \%$ of total fluid volume [25]. The experiment was carried out under PEG molecular crowding condition ( $30 \%$ of total volume) in this study. PEG molecular crowding conditions and not crowding conditions were compared with UV and CD, and the PEG molecular crowding condition did not affect the interaction between bis-Ru-bpp complex and DNA. Reduced linear dichroism $\left(\mathrm{LD}^{\mathrm{r}}\right)$, defined by the division of measured LD by isotropic absorption spectrum, is related to the angle, $\alpha$, of the transition moment of any DNA-bound drug with respect to the local DNA helix axis through:

$$
\mathrm{LD}^{\mathrm{r}}=1.5 S\left(\left\langle 3 \cos ^{2} \alpha\right\rangle-1\right)
$$

where $S$ is the orientation factor which is the measure of the orient ability of the sample such that $S=1$ for a perfectly oriented sample and $S=0$ for a random orientation. The electric transition moments of an intercalated drug usually appeared to be negative with its magnitude either comparable or larger than that of the DNA absorption region [26,27]. Fluorescence measurements were performed on a FS-2 (SINCO, Seoul, Korea). Excitation and emission wavelengths were 440 and $614 \mathrm{~nm}$, respectively. Slit widths were $10 / 10 \mathrm{~nm}$

\section{Results}

\subsection{Absorption and Circular Dichroism}

The absorption spectra of bis-Ru-bpp complex bound to various polynucleotides such as poly $\left[\mathrm{d}(\mathrm{A}-\mathrm{T})_{2}\right](\mathrm{a})$, poly $\left[\mathrm{d}(\mathrm{G}-\mathrm{C})_{2}\right](\mathrm{b})$ and poly $\left[\mathrm{d}(\mathrm{I}-\mathrm{C})_{2}\right]$ (c) were shown in Figure 1 in the presence(solid curve) and in the absence (dash curve) of DNAs. For easy comparison, the absorption spectrum of DNA was removed from the absorption spectrum of DNA-bis-Ru-bpp. Uv spectra measured at [bis-Ru-bpp] $/$ [polynucleotide] $=0.02,0.04,0.06,0.08$, and 0.10 (where [polynucleotide] $=100 \mu \mathrm{M}$ ) were identical when normalized to its concentration (Figure S1), suggesting that the binding mode was homogeneous in this range of concentration. Therefore, the only result at [bis-Ru-bpp]/[polynucleotide] $=0.10$ is shown for clarity reason. The transition between ligands in dppz $\left(\pi^{*} \leftarrow \pi\right)$ was shown at $373 \mathrm{~nm}$ which indicates the highest absorbance between $300 \mathrm{~nm}$ and $550 \mathrm{~nm}$ in absorption spectrum of bis-Ru-bpp complex, and MLCT absorption was shown in the long-wave side. Red shift occurred for $9 \mathrm{~nm}$ from 372 to $382 \mathrm{~nm}$ which was the transition region between ligands when it was bonded 
to DNA, and there was no movement in $440 \mathrm{~nm}$ which was the MLCT area. For hypochroism, $382 \mathrm{~nm}(17.20 \%)$ and $440 \mathrm{~nm}(19.10 \%)$ were shown in case of poly[d(A-T) 2$], 382 \mathrm{~nm}(23.66 \%)$ and $440 \mathrm{~nm}(19.14 \%)$ in case of poly[d(G-C) $)_{2}$, and lastly $382 \mathrm{~nm}(13.98 \%)$ and $440 \mathrm{~nm}(18.68 \%)$ in case of poly[d(I-C) $)_{2}$. Hypochroism occurs most noticeably in the case of bis-Ru-bpp complex and poly $\left[\mathrm{d}(\mathrm{G}-\mathrm{C})_{2}\right]$ (Figure 1a). Although the stacking interaction of the bis-Ru-bpp complex with nucleobase seems to be the largest for poly $\left[\mathrm{d}(\mathrm{G}-\mathrm{C})_{2}\right]$, hypochromism in the absorption spectrum it is not necessarily absolute measure for the extent of stacking interaction $(\pi-\pi$ interaction between expanded dppz ligand and DNA bases, see below). Absorption occurs at the area of 200-300 nm for both bis-Ru-bpp complex and DNA. The absorption in this area applies to bis-Ru-bpp complex, or DNA or both of them so that it cannot be distinguishable, preventing further discussion for absorption change in this area. The CD spectra of bis-Ru-bpp at various polynucleotides are shown in Figure 2. The CD spectrum of bis-Ru-bpp is also altered as it binds to DNA (Figure 2). There is no CD band in the absence of polynucleotides because it is racemic mixture. However, when bis-Ru-bpp complex was bound to DNAs, positive metal-to-ligand charge transfer (MLCT) CD spectra was appeared at $471 \mathrm{~nm}$ for poly $\left[\mathrm{d}(\mathrm{A}-\mathrm{T})_{2}\right]$, and $476 \mathrm{~nm}$ for both poly $\left[\mathrm{d}(\mathrm{I}-\mathrm{C})_{2}\right]$, and poly $\left[\mathrm{d}(\mathrm{G}-\mathrm{C})_{2}\right]$, by DNA. The signal corresponding to the dppz ligand absorption region is very small. The CD signal below $300 \mathrm{~nm}$ reflects the sum of the CD spectrum of DNA and that of bis-Ru-bpp complex: the change in CD spectrum in this region originates from a change in both chromophores. At this stage, these two contributions cannot be separated and therefore, will not be discussed further.

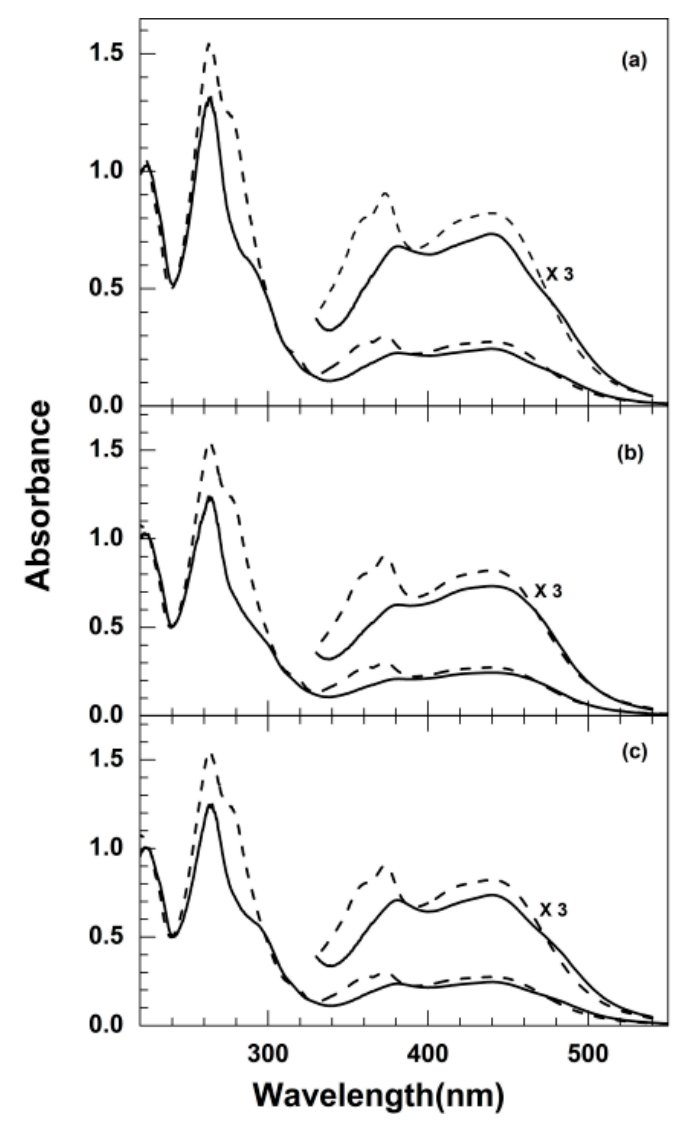

Figure 1. (a) Absorption spectra of bis-Ru-bpp bound to poly[d(A-T) $\left.)_{2}\right]$, (b) poly[d(G-C) 2$]$ and (c) poly $\left[\mathrm{d}(\mathrm{I}-\mathrm{C})_{2}\right]$ in the presence (solid curve) and absence (dash curve) of DNA. [DNA] $=100 \mu \mathrm{M}$, [bis-Ru-bpp] $=10.0 \mu \mathrm{M}(20.0 \mu \mathrm{M}$ in the dppz). The absorption spectra of DNA were subtracted and the spectra enlarged three times are shown at long wavelength for ease of comparison. The absorption spectra of the bis-Ru-bpp bound to DNA at a concentration range below $10.0 \mu \mathrm{M}$ were identical for all DNAs. 


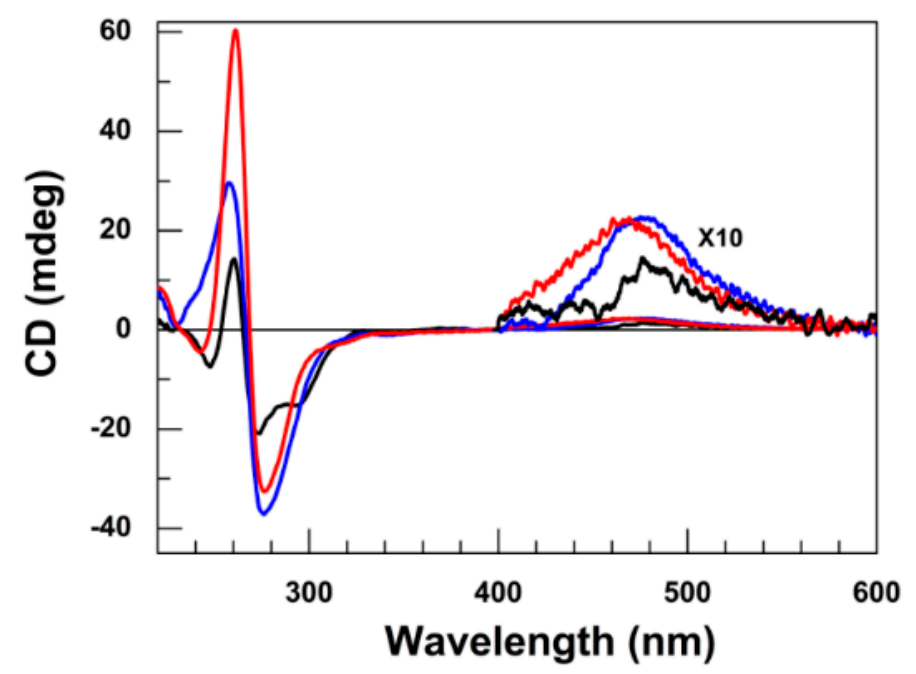

Figure 2. CD spectra of bis-Ru-bpp in the presence of poly[d(A-T $\left.)_{2}\right]$ (red curve), poly[d(G-C $\left.)_{2}\right]$ (black curve) and poly $\left[\mathrm{d}(\mathrm{I}-\mathrm{C})_{2}\right]$ (blue curve). The spectra enlarged 10 times shown at long wavelength for ease of comparison. The concentration is the same in Figure 1.

\section{2. $L D^{r}$ Spectra}

Polynucleotides used in this research including poly $\left[\mathrm{d}(\mathrm{A}-\mathrm{T})_{2}\right]$, poly $\left[\mathrm{d}(\mathrm{G}-\mathrm{C})_{2}\right]$, and poly $\left[\mathrm{d}(\mathrm{I}-\mathrm{C})_{2}\right]$ were too short to be oriented in the flow and thus no LD spectrum was observable. In order to enhance the orientation ability of polynucleotides, PEG (30\% of total volume) was added, which increased the viscosity of medium and hence, resulted in a clearer LD spectra. The presence of PEG did not affect Uv and CD spectrum (Figures S2 and S3, respectively), suggesting that it did not affect the binding mode of the bis-Ru complex to any of these polynucleotides. $\mathrm{LD}^{\mathrm{r}}$ spectra which were obtained by division of measured LD by absorption spectrum are depicted in Figure 3. At a glance, $\mathrm{LD}^{\mathrm{r}}$ signal in the DNA absorption region was negative for all polynucleotides as it was expected from the set-up adopted in this study, reflecting that the nucleobases were oriented perpendicular to the flow direction or the DNA helix axis. The magnitude of $\mathrm{LD}^{\mathrm{r}}$ of the bis-Ru-bpp-polynucleotides complex in DNA absorption region decreased significantly compared to that of the Ru complex-free polynucleotides, indicating that DNA bent or tilted to a significant extent upon binding of the bis-Ru complex.

This suggested that the average direction of the intra ligand electric transition lies near parallel to the DNA helix axis. A strong negative signal observed at $c a$. $330 \mathrm{~nm}$ for poly $\left[\mathrm{d}(\mathrm{A}-\mathrm{T})_{2}\right]$ and poly $\left[\mathrm{d}(\mathrm{I}-\mathrm{C})_{2}\right]$ with its magnitude larger or comparable to that in the DNA absorption region, corresponding to electric transition alone the expanded dppz ligand, suggested that the molecular plane of the both dppz moiety of bis-Ru-bpp lies perpendicular relative to the DNA helix axis (parallel to nucleobases). This observation is strong evidence for the intercalation of the dppz ligand. On the other hand, this $\mathrm{LD}^{\mathrm{r}}$ signal of the bis-Ru-bpp complexed with poly $\left[\mathrm{d}(\mathrm{G}-\mathrm{C})_{2}\right]$ was significantly smaller compared to the other two polynucleotides, and to that in the DNA absorption region, suggesting that the binding mode of the bis-Ru-bpp when formed an adduct with poly $\left[\mathrm{d}(\mathrm{G}-\mathrm{C})_{2}\right]$ was significantly deviated from bis-intercalation. In the MLCT region (400-500 nm), very strong wavelength-dependence in the $\mathrm{LD}^{\mathrm{r}}$ spectrum was observed, which is typical for $\left[\operatorname{Ru}(\text { phen })_{2} L\right]^{2+}$ complexes $[28,29]$. The direction of electric transitions in the MLCT is complicated [29] and is not directly related to the current discussion. Therefore, further lengthy discussion for $\mathrm{LD}^{\mathrm{r}}$ spectrum in this region is avoided. 


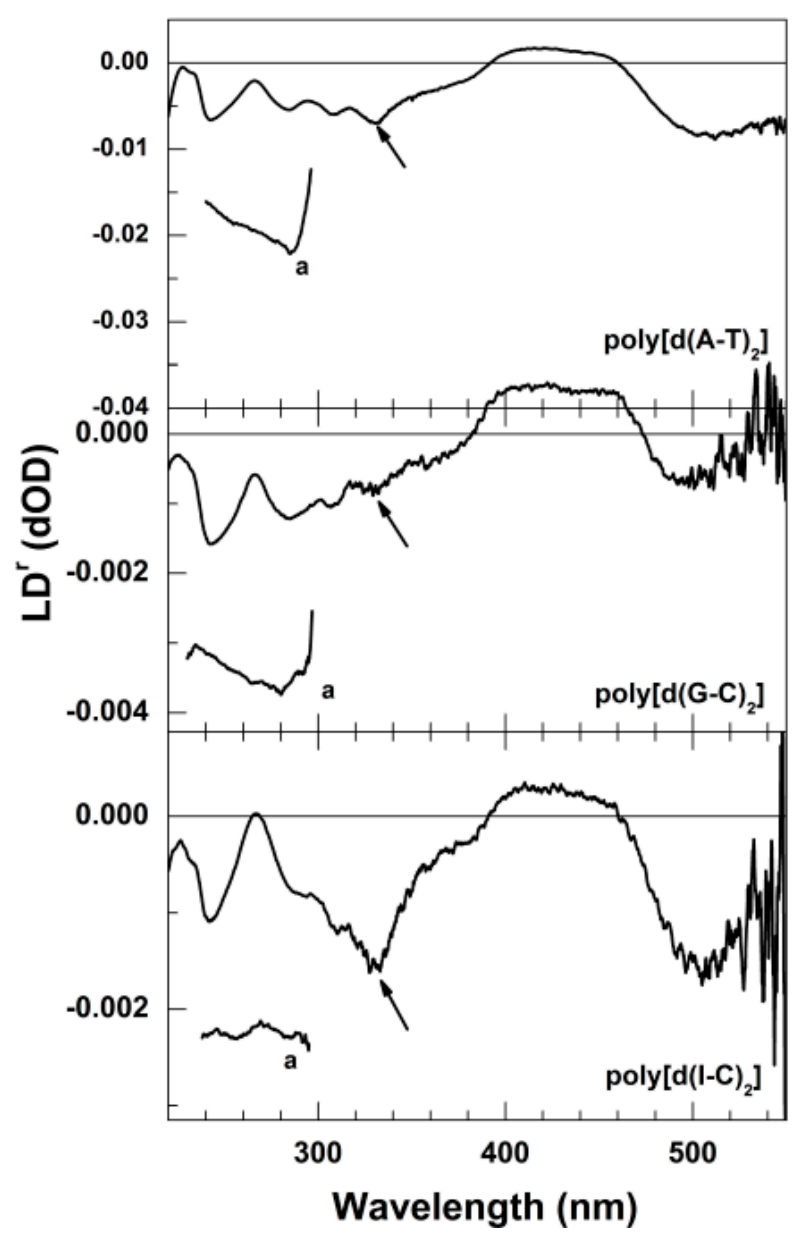

Figure 3. $\mathrm{LD}^{\mathrm{r}}$ spectra of of bis-Ru-bpp bound to poly[d(A-T $\left.)_{2}\right]$, poly $\left[\mathrm{d}(\mathrm{G}-\mathrm{C})_{2}\right]$, and poly $\left[\mathrm{d}(\mathrm{I}-\mathrm{C})_{2}\right]$. Symbol a denotes $\mathrm{LD}^{\mathrm{r}}$ spectra of corresponding polynucleotides in the absence of the bis-Ru-bpp complex. The concentration is the same in Figure 1. The absorption band ca. $330 \mathrm{~nm}$, corresponding to the electronic transition moment lies along the long axis of the dppz ligand, is marked by arrows.

\subsection{Luminescence and Quenching Measurement}

Although the quantum yield of $\left[R u(p h e n)_{2} d p p z\right]^{2+}$ is negligibly small in aqueous solution, it is well known and is denoted as the "light switch effect" that the emission intensity increases upon the intercalation of the DPPZ ligand between the DNA base-pairs [28,30,31]. A similar increase in the emission intensity was observed for various polynucleotides. At a constant DNA concentration, the emission intensities for the complexes increase almost proportionally to their concentrations (Figure 4). The highest emission intensity is shown in poly $\left[\mathrm{d}(\mathrm{A}-\mathrm{T})_{2}\right]$ and poly $\left[\mathrm{d}(\mathrm{G}-\mathrm{C})_{2}\right]$ when the ratio between bis-Ru-bpp complex concentration and DNA concentration becomes $\sim 0.4$, and the intensity decreases slightly as the complex concentration increases. Although, the concentration ratio at the highest position is not clear in case of poly $\left[\mathrm{d}(\mathrm{I}-\mathrm{C})_{2}\right]$, but the saturation ratio seems to be $\sim 0.4$. Unlike poly $\left[\mathrm{d}(\mathrm{A}-\mathrm{T})_{2}\right]$, poly $\left[\mathrm{d}(\mathrm{G}-\mathrm{C})_{2}\right]$ and poly $\left[\mathrm{d}(\mathrm{I}-\mathrm{C})_{2}\right]$ did not produce a decrease in the emission intensity at high mixing ratios. When bis-Ru-bpp complex is bound to polynucleotides, the emission intensity at the highest position is almost same in case of poly[d(A-T $\left.)_{2}\right]$ and poly $\left[\mathrm{d}(\mathrm{I}-\mathrm{C})_{2}\right]$, but the emission intensity becomes a value which is three times lower when it is bound to poly $\left[\mathrm{d}(\mathrm{G}-\mathrm{C})_{2}\right]$. This indicates that the environment varies when bis-Ru-bpp complex is bound with poly $\left[\mathrm{d}(\mathrm{G}-\mathrm{C})_{2}\right]$, poly $\left[\mathrm{d}(\mathrm{A}-\mathrm{T})_{2}\right]$ or poly $\left[\mathrm{d}(\mathrm{I}-\mathrm{C})_{2}\right]$. Using the change in emission intensity, the binding stoichiometry for the bis-Ru-bpp complexation with polynucleotides was investigated using the Job method (Figure $4 b$ ). From the Job plot, the highest intensity was found at the bis-Ru-bpp ratio of $0.2 \sim 0.25$ relative to polynucleotide base, 
indicating that bis-Ru-bpp binds to four polynucleotide bases or two base pairs. This observation is the same as its monomer, $\left[R u(p h e n)_{2} d p p z\right]^{2+}[29]$.
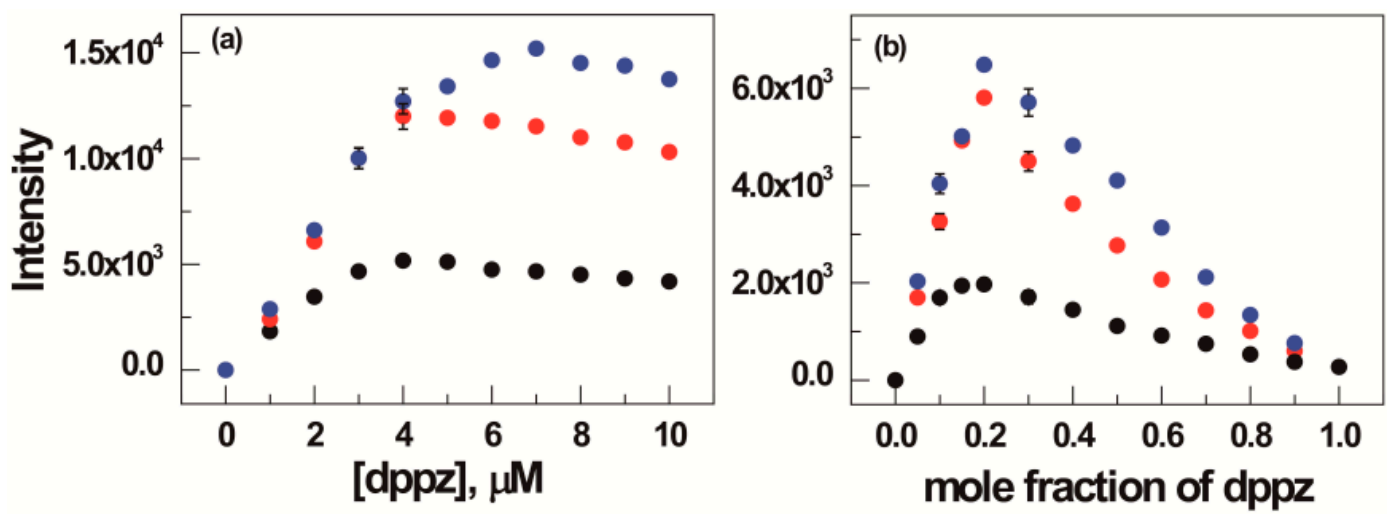

Figure 4. (a) Change in emission intensity of the bis-Ru-bpp with increasing complex concentration. Slit widths for both excitation and emission were $10 \mathrm{~nm}$. [DNA] $=10 \mu \mathrm{M}$, [bis-Ru-bpp] $=0.5-5 \mu \mathrm{M}$ with an increment of $0.5 \mu \mathrm{M}$. Red, black, and blue circles denote poly[d(A-T $\left.)_{2}\right]$, poly $\left[\mathrm{d}(\mathrm{G}-\mathrm{C})_{2}\right]$, and poly $\left[\mathrm{d}(\mathrm{I}-\mathrm{C})_{2}\right]$ respectively. (b) Job plot for complex formation of bis-Ru-bpp with various polynucleotides. Excitation and emission wavelengths were $440 \mathrm{~nm}$ and $614 \mathrm{~nm}$, respectively.

It is noticed that the luminescence intensity of polynucleotide bound bis-Ru-bpp complex was the lowest in the poly $\left[\mathrm{d}(\mathrm{G}-\mathrm{C})_{2}\right]$ case (Figure $\left.4 \mathrm{a}\right)$. Considering the factors that the minor groove resemble for poly $\left[\mathrm{d}(\mathrm{A}-\mathrm{T})_{2}\right]$ and poly $\left[\mathrm{d}(\mathrm{I}-\mathrm{C})_{2}\right]$, while the major groove of poly $\left[\mathrm{d}(\mathrm{G}-\mathrm{C})_{2}\right]$ and poly $\left[\mathrm{d}(\mathrm{I}-\mathrm{C})_{2}\right]$ are similar, the bis-Ru-bpp complex conceivably intercalated from the minor groove where the amine group of guanine base takes role for lower quantum yield. Alternatively, the lower quantum yield of the poly $\left[\mathrm{d}(\mathrm{G}-\mathrm{C})_{2}\right]$-bis-Ru-bpp complex can be elucidated by non-intercalative binding of the second dppz ligand, in which the second dppz ligand may be tethered in the aqueous solvent (see above for binding mode). One of these two facts or both cause the relatively low luminescence quantum yield for poly[d(G-C) $)_{2}$-bis-Ru-bpp complex compared with two others.

The $\left[\mathrm{Fe}(\mathrm{CN})_{6}\right]^{4-}$ ion is a well-known quencher for luminescent of $\left[\mathrm{Ru}(\mathrm{phen})_{2} \mathrm{DPPZ}\right]^{2+}$-DNA complexes [32-34]. The quenching profiles of the emission intensity for various polynucleotides are shown in Figure 5 in the form of the Stern-Volmer (a) and modified Stern-Volmer (b) plots. In the Figure $5 \mathrm{a}$, the emission intensity of the poly[d(A-T $\left.)_{2}\right]-b i s-R u-b p p$, poly $\left[\mathrm{d}(\mathrm{I}-\mathrm{C})_{2}\right]-$ and poly $\left[\mathrm{d}(\mathrm{G}-\mathrm{C})_{2}\right]$-complexes decreases with increasing $\left[\mathrm{Fe}(\mathrm{CN})_{6}\right]^{4-}$ ion concentration. When bis-Ru-bpp bounded to polynucleotides are plotted by the $\left[\mathrm{Fe}(\mathrm{CN})_{6}\right]^{4-}$ concentration $\left(F_{0} / F\right.$ versus $\left.\left[\mathrm{Fe}(\mathrm{CN})_{6}\right]^{4-}\right)$, a normal Stern-Volmer plot), downward curves are observed for bis-Ru-bpp bound to all DNAs (Figure 5a). it was noticed that quenching efficiency is two times and three times higher for the poly $\left[\mathrm{d}(\mathrm{A}-\mathrm{T})_{2}\right]$ compared to that of the poly $\left[\mathrm{d}(\mathrm{I}-\mathrm{C})_{2}\right]$ and poly $\left[\mathrm{d}(\mathrm{G}-\mathrm{C})_{2}\right]$, respectively, with the poly $\left[\mathrm{d}(\mathrm{G}-\mathrm{C})_{2}\right]$ being more inaccessible to the $\left[\mathrm{Fe}(\mathrm{CN})_{6}\right]^{4-}$. On the other hand, the overall accessibility of the $\left[\mathrm{Fe}(\mathrm{CN})_{6}\right]^{4-}$ quencher is far less for bis-Ru-bpp-poly $\left[(\mathrm{G}-\mathrm{C})_{2}\right]$ complex when the mixing ratio is 0.1 . In the case of all bis-Ru-bpp bound to various polynucleotides (ratio $=0.1$ ), appeared to be a downward curvature, this shows that quenching accessible and inaccessibility fluorophores may exist due to the difference in microenvironments when bis-Ru-bpp complex is bound with polynucleotides. Suppose that there are two populations of fluorophores; one being accessible (a) to quenchers and other being inaccessible $(b)$. The total fluorescence in the absence of quencher $\left(F_{0}\right)$ is given by Equation (2) [35], where the:

$$
F_{0}=F_{0 \mathrm{a}}+F_{0 \mathrm{~b}}
$$

subscript 0 refers to the fluorescence intensity in the absence of quencher. In this case, the Stern-Volmer plot can be modified to Equation (3) to calculate the fraction of quencher-accessible: 


$$
F_{0} / \Delta F=1 /\left(f_{\mathrm{a}} K_{\mathrm{a}}[\mathrm{Q}]\right)+f_{\mathrm{a}}^{-1}
$$

fluorophore $\left(f_{\mathrm{a}}\right)$. In Equation (3), $K_{\mathrm{a}}$ is the Stern-Volmer quenching constant for the accessible fraction and $[Q]$ is the concentration of quencher. The modified form of the Stern-Volmer equation allows $f_{\mathrm{a}}$ and $K_{\mathrm{a}}$ to be determined graphically (Figure $5 \mathrm{~b}$ ). Extrapolation to high concentration of $\left[\mathrm{Fe}(\mathrm{CN})_{6}\right]^{4-}$ yields an intercept $3.81\left(f_{\mathrm{a}}=0.26\right), 3.23\left(f_{\mathrm{a}}=0.31\right)$, and $7.38\left(f_{\mathrm{a}}=0.16\right)$ indicating that $26 \%, 31 \%$ and $16 \%$ of the total fluorescence of poly $\left[\mathrm{d}(\mathrm{A}-\mathrm{T})_{2}\right]$, poly $\left[\mathrm{d}(\mathrm{I}-\mathrm{C})_{2}\right]$, and poly $\left[\mathrm{d}(\mathrm{G}-\mathrm{C})_{2}\right]$, respectively. Also, $K_{\mathrm{a}}$ has a value of $0.304,0.348$, and 0.124 for poly $\left[\mathrm{d}(\mathrm{A}-\mathrm{T})_{2}\right]$, poly $\left[\mathrm{d}(\mathrm{I}-\mathrm{C})_{2}\right]$ and poly $\left[\mathrm{d}(\mathrm{G}-\mathrm{C})_{2}\right]$ respectively. Poly $\left[\mathrm{d}(\mathrm{G}-\mathrm{C})_{2}\right]$ has a value which is three times smaller in comparison to $K_{\mathrm{a}}$ of both poly[d(A-T $\left.)_{2}\right]$ and poly[d(I-C) $\left.)_{2}\right]$. This suggests that both dppz moiety in the bis-Ru-bpp complex bound to polynucleotides are equally fluorescent and are accessible or inaccessible by quencher according to difference in the binding environment, and in case of poly $\left[\mathrm{d}(\mathrm{G}-\mathrm{C})_{2}\right]$ it has a value which is three times smaller in comparison to other polynucleotides.
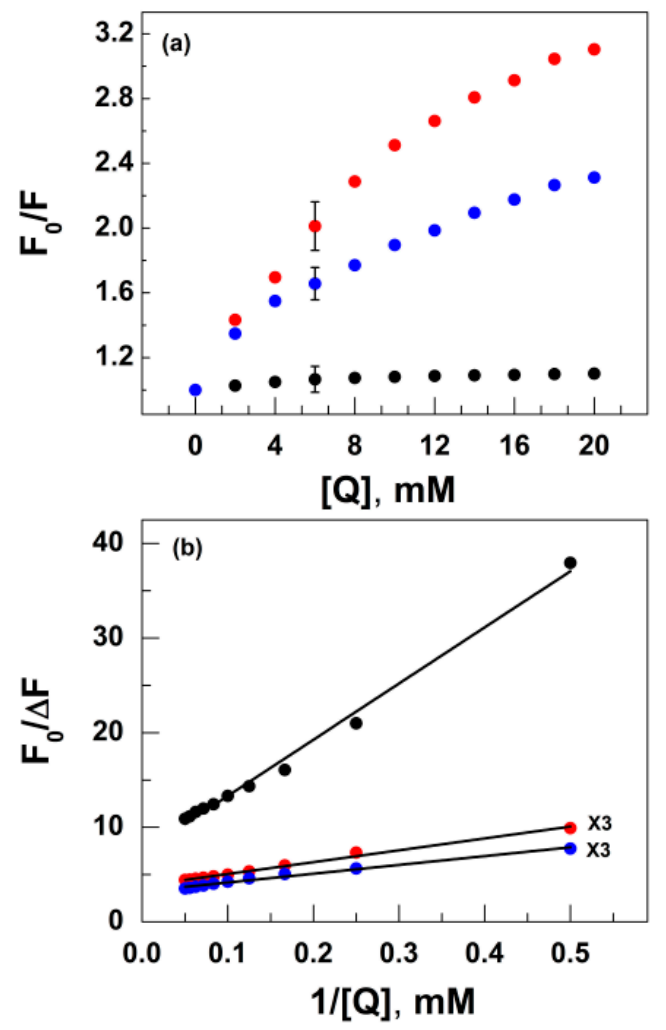

Figure 5. The Stern-Volmer (a) and modified Stern-Volmer (b) plots for the quenching of fluorescence intensity of bis-Ru-bpp bound to polynucleotides by $\left[\mathrm{Fe}(\mathrm{CN})_{6}\right]^{4-}$. The conditions used to measure emission intensity are identical to those in Figure 4. [DNA] $=10 \mu \mathrm{M},\left[\mathrm{Fe}(\mathrm{CN})_{6}\right]^{4-}=2-20 \mathrm{mM}$ with an increment of $2 \mathrm{mM}$. Red, black, and blue circles denote poly[d(A-T) 2$]$, poly $\left[\mathrm{d}(\mathrm{G}-\mathrm{C})_{2}\right]$, and poly $\left[\mathrm{d}(\mathrm{I}-\mathrm{C})_{2}\right]$, respectively.

\section{Discussion}

Binding Properties of Bis-Ru-Bpp Complex Bound to Polynucleotides

The binding properties shown when bis-Ru-bpp complex was bound to various polynucleotides were compared in this study. The spectral properties of the bis-Ru-bpp-poly[d(A-T $\left.)_{2}\right]$ and -poly[d(I-C $\left.)_{2}\right]$ adducts are summarized as hypochromism and red shift in the entire absorption range. This effect is especially noticeable the dppz ligand absorption region $(\sim 320 \mathrm{~nm}$ and $\sim 400 \mathrm{~nm})$. The magnitude of $L D^{\mathrm{r}}$ 
in this region is comparable or larger than that of the DNA absorption region, supporting that the long transition axis of both dppz ligand is close to perpendicular relative to the local DNA helix axis. On the other hand, the magnitude of $\mathrm{LD}^{\mathrm{r}}$ of the bis-Ru-bpp-poly[d(G-C) $)_{2}$ in the same region was significantly lower compared to the other two polynucleotides, suggesting some deviation from the bis-intercalative binding mode. In the luminescence experiment, the luminescence intensity of bis-Ru-bpp complex upon binding to polynucleotides was increased. The increase for both bis-Ru-bpp-poly[d(A-T $\left.)_{2}\right]$, and poly $\left[\mathrm{d}(\mathrm{I}-\mathrm{C})_{2}\right]$ was more effective compared to that of bis-Ru-bpp-poly $\left[\mathrm{d}(\mathrm{G}-\mathrm{C})_{2}\right]$ adduct. This indicates that dppz ligand is protected from the water molecules and interacts with the DNA bases at the binding site. It is also noteworthy that the equilibrium constant for complex formation was the lowest for poly $\left[\mathrm{d}(\mathrm{G}-\mathrm{C})_{2}\right]$ although all added bis-Ru-bpp was bound to polynucleotide in the concentration range adopted in this study. The mixing ratio-independent absorption spectrum for all three adducts also supports binding of all Ru complexes to polynucleotides and the homogeneous binding mode within the same polynucleotide. The luminescence quenching experiment showed that $\left[\mathrm{Fe}(\mathrm{CN})_{6}\right]^{4-}$ is an effective quencher. The shape of the Stern-Volmer quenching plot appeared to be a downward bending curve. This type of quenching curve may be elucidated by the presence of two type of luminescent molecules: one completely protected from outside quencher and the other partially accessible fraction. Although the accessible portion of the bis-Ru-bpp is the lowest, accessibility of negatively charged quencher is the highest for poly $\left[\mathrm{d}(\mathrm{G}-\mathrm{C})_{2}\right]$, suggesting that the bis-Ru-bpp is exposed more when bound to poly $\left[\mathrm{d}(\mathrm{G}-\mathrm{C})_{2}\right]$ than the other two polynucleotides. Environment and accessibility of the $\left[\mathrm{Fe}(\mathrm{CN})_{6}\right]^{4-}$ quencher seemed to lowest for poly $\left[\mathrm{d}(\mathrm{G}-\mathrm{C})_{2}\right]$. It was reported [20] that both of dppz ligand of the bis-Ru-bpp complex intercalated between DNA base-pairs when bound to native, mixed sequence DNA. Observed spectral properties resembling those observed for poly $\left[\mathrm{d}(\mathrm{A}-\mathrm{T})_{2}\right]$ and poly $\left[\mathrm{d}(\mathrm{I}-\mathrm{C})_{2}\right]$, led us to conclude that both dppz ligands intercalate between alternated AT and IC bases-pairs. In contrast, the spectral properties of the bis-Ru-bpp-poly $\left[\mathrm{d}(\mathrm{G}-\mathrm{C})_{2}\right]$ complex, especially $\mathrm{LD}^{\mathrm{r}}$ and enhancement in luminescence intensity suggested deviation from the bis-intercalation model in the poly[d(G-C) 2$]$ case.

From these observations, a binding mode of the bis-Ru-bpp to poly $\left[\mathrm{d}(\mathrm{G}-\mathrm{C})_{2}\right]$ can be proposed in which one dppz moiety is intercalated and the other is exposed to solvent or tethered into one of the groove. Alternatively, both dppz ligands deviated from full intercalative binding. They may be quasi-intercalated exhibiting the average angle between molecular plane of dppz ligand and the DNA helix axis significantly less than $90^{\circ}$ [36]. The former model may be considered as an extreme case for deviation. In any case, the amine group of guanine in the minor groove provides the steric hindrance for incoming intercalating dppz, resulting in the deviated binding mode. The presence of the amine group may also take a role for less efficient increase in the luminescence intensity upon association with poly[d(G-C) $)_{2}$. Figure 6 shows a schematic diagram, in which one of the dppz ligands in bis-Ru-bpp intercalates between DNA base-pairs while the other is exposed to solvent.

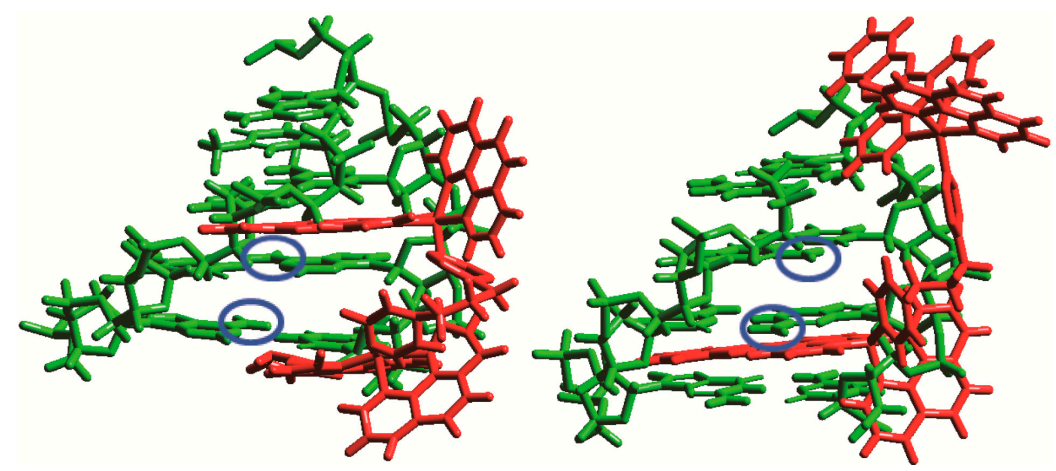

Figure 6. Schematic diagrams of the bis-Ru-bpp-complex-DNA. Both the dppz ligands intercalate between the DNA base-pairs (left diagram) in case of poly[d(A-T $\left.)_{2}\right]$ and one dppz is intercalated and the other exposed to solvent (right diagram) in case of poly $\left[\mathrm{d}(\mathrm{G}-\mathrm{C})_{2}\right]$. The blue circle indicates position of amine group in minor groove direction. 


\section{Conclusions}

Both dppz ligands of the bis-Ru-bpp complex intercalate between polynucleotide base pairs. The binding properties of them are selective toward the sequences of the DNA base pairs. Due to structural differences of DNA sequences, when bis-Ru-bpp complex is bound to poly[d(A-T $\left.)_{2}\right]$ and poly $\left[\mathrm{d}(\mathrm{I}-\mathrm{C})_{2}\right]$, both of the two dppz ligands are intercalated, and on the contrary, in the case of poly $\left[\mathrm{d}(\mathrm{G}-\mathrm{C})_{2}\right]$, one dppz ligand is intercalated between the sequences and the other one is exposed outside from the solvent. Alternatively, both dppz ligands deviated from full intercalative binding.

Supplementary Materials: The following are available online at www.mdpi.com/2075-4701/6/6/141/s1. Figure S1: Normalized absorption spectra of bis-Ru-bpp bound to poly[d(A-T)2], poly[d(G-C)2] and poly[d(I-C)2] DNA. $[\mathrm{DNA}]=100 \mu \mathrm{M}$, [bis-Ru-bpp] $=2.0,4.0,6.0,8.0,10.0 \mu \mathrm{M}$. The absorption spectra of DNA were subtracted for ease of comparison. The absorption spectra of the bis-Ru-bpp bound to DNA at a concentration range below $10.0 \mu \mathrm{M}$ were identical for all DNAs, Figure S2: Absorption spectra of bis-Ru-bpp bound to poly[d(A-T)2], poly[d(G-C)2] and poly[d(I-C)2] in peg(black curve) and not in peg (red curve) condition. [DNA]= $100 \mu \mathrm{M}$, $[$ bis-Ru-bpp] $=10.0 \mu \mathrm{M}$, Figure S3: CD spectra of bis-Ru-bpp bound to poly[d(A-T)2], poly[d(G-C)2] and poly[d(I-C)2] in peg(black curve) and not in peg (red curve) condition. The concentration is the same in Figure 1.

Acknowledgments: This work was supported by the National Research Foundation (Grant No.: 2011-0013534).

Author Contributions: Barai H.R. performed the major part of the experiments; Lee D.J. and Han S.W. performed the initial part of the experiments. Jang Y.J. wrote the manuscript and supervised this study.

Conflicts of Interest: The authors declare no conflict of interest.

\section{Abbreviations}

The following abbreviations are used in this manuscript:

PEG: PolyethyleneGlycole

CD: $\quad$ Circular dichrosim

LD: $\quad$ Linear dichroism

\section{References}

1. Kastan, M.B.; Bartek, J. Cell-cycle checkpoints and cancer. Nature 2004, 432, 316-323. [CrossRef] [PubMed]

2. Erkkila, K.E.; Odem, D.T.; Barton, J.K. Recognition and reaction of metallointercalators with DNA. Chem. Rev. 1999, 99, 2777-2796. [CrossRef] [PubMed]

3. Metcalf, C.; Thomas, J.A. Kinetically inert transition metal complexes that reversibly bind to DNA. Chem. Soc. Rev. 2003, 23, 215-524. [CrossRef]

4. Xiong, Y.; Ji, L.N. Synthesis, DNA binding and DNA mediated luminescence quenching of Ru(II)polypyridine complexes. Coord. Chem. Rev. 1999, 185, 711-733. [CrossRef]

5. Blasius, R.; Moucheron, C.; Mesmaeker, A.K.-D. Photoadducts of Metallic Compounds with Nucleic Acids-Role Played by the Photoelectron Transfer Process and by the TAP and HAT Ligands in the $\mathrm{Ru}^{\mathrm{II}}$ Complexes. Eur. J. Inorg. Chem. 2004, 20, 3971-3979. [CrossRef]

6. Nordén, B.; Lincoln, P.; Akerman, B.; Tuite, E. Metal Ions in Biological System; Sigel, A., Sigel, S., Eds.; Marcel Dekker: New York, NY, USA, 1996; Volume 33, pp. 177-252.

7. Delaney, S.; Yoo, J.; Stemp, E.D.A.; Barton, J.K. Charge equilibration between two distinct sites in double helical DNA. Proc. Natl. Acad. Sci. USA 2004, 101, 10511-10516. [CrossRef] [PubMed]

8. Brabec, V.; Kasparkova, J. Modifications of DNA by platinum complexes: Relation to resistance of tumors to platinum antitumor drugs. Drug Resist. Updates 2005, 8, 131-146. [CrossRef] [PubMed]

9. Hannon, M.J. Metal-based anticancer drugs: From a past anchored in platinum chemistry to a post-genomic future of diverse chemistry and biology. Pure Appl. Chem. 2007, 79, 2243-2261. [CrossRef]

10. Clarke, M.; Zhu, F.; Frasca, D.R. Non-Platinum Chemotherapeutic Metallopharmaceuti-cals. Chem. Rev. 1999, 99, 2511-2533. [CrossRef] [PubMed]

11. Mazumder, U.K.; Gupta, M.; Karki, S.S.; Battacharya, S.; Rathinasamy, S.; Sivakumar, T. Synthesis and pharmacological activities of some mononuclear Ru(II) complexes. Bioorg. Med. Chem. 2005, 13, 5766-5773. [CrossRef] [PubMed] 
12. Schluga, P.; Hartinger, C.; Egger, A.; Reisner, E.; Galanski, M.; Jakupec, M.A.; Keppler, B.K. Redox behavior of tumor-inhibiting ruthenium (III) complexes and effects of physiological reductants on their binding to GMP. Dalton Trans. 2006, 14, 1796-1802. [CrossRef] [PubMed]

13. Önfelt, B.; Lincoln, P.; Nordén, B. Femtosecond linear dichroism of DNA-intercalating chromophores: Solvation and charge separation dynamics of $\left[\mathrm{Ru}(\mathrm{phen})_{2} \mathrm{dppz}\right]^{2+}$ systems. Proc. Natl. Acad. Sci. USA 2000, 97, 5708-5713. [CrossRef] [PubMed]

14. Önfelt, B.; Lincoln, P.; Nordén, B. Enantioselective DNA threading dynamics by phenazine-linked $\left[R u(\text { phen })_{2} \text { dppz] }\right]^{2+}$ dimers. J. Am. Chem. Soc. 2001, 123, 3630-3637. [CrossRef] [PubMed]

15. Metcalfe, C.; Haq, I.; Thomas, J.A. A Facile Route to Bimetallic Ruthenium Dipyrido-phenazine Complexes. Inorg. Chem. 2004, 43, 317-323. [CrossRef] [PubMed]

16. Pierard, F.; Mesmaeker, A.K.-D. Bifunctional transition metal as nucleic acid photoprobes and photoreagents. Inorg. Chem. Commun. 2006, 9, 111-126. [CrossRef]

17. Wilhelmsson, L.M.; Westerlund, F.; Lincoln, P.; Nordén, B. DNA-Binding of Semi-Rigid Binuclear Ruthenium Complex $\left.\Delta, \Delta-\left[\mu-11-11^{\prime} \text {-bidppz)(phen }\right)_{4} \mathrm{Ru}_{2}\right]^{4+}$ : Extremely Slow Intercalation Kinetics. J. Am. Chem. Soc. 2002, 124, 12092-12093. [CrossRef] [PubMed]

18. Nordell, P.; Westerlund, F.; Wilhelmsson, L.M.; Nordén, B.; Lincoln, P. Kinetic Recognition of AT-Rich DNA by Ruthenium Complexes. Angew. Chem. Int. Ed. 2007, 46, 2203-2206. [CrossRef] [PubMed]

19. Jang, Y.J.; Kwon, B.H.; Choi, B.H.; Bae, C.H.; Seo, M.S.; Nam, W.; Kim, S.K. Intercalation of bulky $\Delta, \Delta$ - and $\Lambda, \Lambda$-bis-Ru(II) complex between DNA base pairs. J. Inorg. Biochem. 2008, 102, 1885-1891. [CrossRef] [PubMed]

20. Kwon, B.H.; Choi, B.H.; Lee, H.M.; Jang, Y.J.; Lee, J.C.; Kim, S.K. Binding Modes of New Bis-Ru(II) Complexes to DNA: Effect of the Length of the Linker. Bull. Korean Chem. Soc. 2010, 31, 1615-1620. [CrossRef]

21. Duval-Valentine, G.; Thuong, N.T.; Hélène, C. Specific inhibition of transcription by triple helix-forming. Proc. Natl. Acad. Sci. USA 1992, 89, 504-508. [CrossRef]

22. Giovannangeli, C.; Thuong, N.T.; Hélène, C. Specific inhibition of transcription by triple helix-forming oligonucleotides. Proc. Natl. Acad. Sci. USA 1993, 90, 10013-10017. [CrossRef] [PubMed]

23. Hanvey, J.C.; Shimizu, M.; Wells, R.D. Site-specific inhibition of EcoRI restriction/modifi-cation enzymes by a DNA triple helix. Nucleic Acid Res. 1990, 18, 157-161. [CrossRef] [PubMed]

24. Johnston, B.H. The S1-sensitive form of $\mathrm{d}(\mathrm{C}-\mathrm{T})_{n} \cdot \mathrm{d}(\mathrm{A}-\mathrm{G})_{n}$ : Chemical evidence for a three-stranded structure in plasmids. Science 1988, 241, 1791-1796. [CrossRef]

25. Fulton, A.B. How crowded is the cytoplasm? Cell 1982, 30, 345-347. [CrossRef]

26. Moon, J.H.; Kim, S.K.; Sehlstedt, U.; Rodger, A.; Nordén, B. DNA structural features responsible for sequence-dependent binding geometries of Hoechst 33258. Biopolymers 1996, 38, 593-606. [CrossRef]

27. Tuite, E.; Nordén, B. Intercalative interactions of ethidium dyes with triplex structures. Bioorg. Med. Chem. 1995, 3, 701-711. [CrossRef]

28. Youn, M.R.; Moon, S.J.; Lee, B.W.; Lee, D.J.; Kim, J.M.; Kim, S.K.; Lee, C.S. DNA Mediated Energy Transfer from 4',6-Diamidino-2-phenylindole to $\mathrm{Ru}$ (II)[(1,10-phenanthroline $\left.)_{2} \mathrm{~L}\right]^{2+}$ : Effect of Ligand Structure. Bull. Korean Chem. Soc. 2005, 26, 537-542.

29. Lincoln, P.; Broo, A.; Norden, B. Diastereomeric DNA-Binding Geometries of Intercalated Ruthenium(II) Trischelates Probed by Linear Dichroism: $\left[\mathrm{Ru}\left(\text { phen }{ }_{2} \mathrm{DPPZ}\right]^{2+}\right.$ and $\left[\mathrm{Ru}(\mathrm{phen})_{2} \mathrm{BDPPZ}\right]^{2+}$. J. Chem. Soc. 1996, 118, 2644-2653. [CrossRef]

30. Lee, B.W.; Moon, S.J.; Youn, M.R.; Kim, J.H.; Jang, H.G.; Kim, S.K. DNA Mediated Resonance Energy Transfer from $4^{\prime}, 6$-Diamidino-2-Phenylindole to $\left[\mathrm{Ru}(1,10-P h e n a n t h r o l i n e)_{2} \mathrm{~L}\right]^{2+}$. Biophys. J. 2003, 85, 3865-3871. [CrossRef]

31. Yun, B.H.; Kim, J.O.; Lee, B.W.; Lincoln, P.; Nordén, B.; Kim, J.M.; Kim, S.K. Simultaneous binding of $\mathrm{Ru}(\mathrm{II})\left[\left(1,10 \text {-phenanthroline }{ }_{2} \text { dipyridophenazine }\right]^{2+}\right.$ and minor groove binder $4^{\prime}$,6-diamino-2-phenylindole to poly $\left[\mathrm{d}(\mathrm{A}-\mathrm{T})_{2}\right]$ at high binding densities. J. Phys. Chem. B 2003, 107, 9858-9864. [CrossRef]

32. Nair, R.B.; Cullum, B.M.; Murphy, C.J. Optical Properties of $\left[\mathrm{Ru}(\mathrm{phen})_{2} \mathrm{dppz}\right]^{2+}$ as a Function of Nonaqueous Environment. Inorg. Chem. 1997, 36, 962-965. [CrossRef] [PubMed]

33. Jenkins, Y.; Friedman, A.E.; Turro, N.J.; Barton, J.K. Characterization of dipyridophenazine complexes of ruthenium(II)-The light switch effect as a function of nucleic-acid sequence and conformation. Biochemistry 1992, 31, 10809-10816. [CrossRef] [PubMed] 
34. Maheswari, P.U.; Rajendiran, V.; Palaniandavar, M.; Parthasarathi, R.; Subramanian, V.J. Synthesis, characterization and DNA-binding properties of $r a c-\left[R u(5,6-\mathrm{dmp})_{2}(\mathrm{dppz})\right]^{2+}$-enantiopreferential DNA binding and co-ligand promoted exciton coupling. J. Inorg. Biochem. 2006, 100, 3-17. [CrossRef] [PubMed]

35. Lakowicz, J.R. Principles of Fluorescence Spectroscopy; Plenum Press: New York, NY, USA, 1990; p. 248.

36. Hiort, C.; Nordén, B.; Rodger, A. Enantiopreferential DNA binding of $\left[\mathrm{Ru}^{\mathrm{II}} \text { (phenanthroline) }{ }_{3}\right]^{2+}$ studied with linear and circular dichroism. J. Am.Chem. Soc. 1990, 112, 1971-1982. [CrossRef]

(C) 2016 by the authors; licensee MDPI, Basel, Switzerland. This article is an open access article distributed under the terms and conditions of the Creative Commons Attribution (CC-BY) license (http://creativecommons.org/licenses/by/4.0/). 